\title{
Plathelminth abundance in North Sea salt marshes: environmental instability causes high diversity
}

\author{
Werner Armonies \\ II. Zoologisches Institut und Museum der Universität; \\ Berliner Str. 28, D-3400 Göttingen \\ and \\ Biologische Anstalt Helgoland (Litoralstation); D-2282 List, FRG
}

\begin{abstract}
Although supralittoral salt marshes are habitats of high environmental instability, the meiofauna is rich in species and abundance is high. The community structure of free-living Plathelminthes (Turbellaria) in these salt marshes is described. On an average, 104 individuals are found below an area of $10 \mathrm{~cm}^{2}$. The average species density in ungrazed salt marshes is 11.3 below $10 \mathrm{~cm}^{2}$ and 45.2 below $100 \mathrm{~cm}^{2}$, indicating strong small-scale heterogenity. The faunal similarity between sediment and the corresponding above-ground vegetation is higher than between adjacent sample sites. Species prefer distinct ranges of salinity. In the lower part of the supralittoral salt marshes, the annual fluctuations of salinity are strongest and highly unpredictable. This region is richest in plathelminth species and abundance; diversity is highest, and the faunal composition of parallel samples is quite similar. In the upper part of the supralittoral salt marshes, the annual variability of salinity is lower, plathelminths are poor in species diversity and abundance. Parallel samples often have no species in common. Thus, those salt marsh regions with the most unstable environment are inhabited by the most diverse species assemblage. Compared to other littoral zones of the North Sea, however, plathelminth diversity in salt marshes is low. The observed plathelminth diversity pattern can apparently be explained by the "dynamic equilibrium model" (Huston, 1979).
\end{abstract}

\section{INTRODUCTION}

Located at the edge of the sea, salt marshes are habitats of harsh environmental conditions, such as salinity, temperature, and submersion. Heavy rainfall can convert supralittoral marshes into transient fresh water biotopes, and evaporation may raise salinity to oversaturation. The sediment may completely desiccate in summer, and during gales the marshes may be flooded for several days. Thus, salt marshes are considered as extreme habitats for all marine, limnic, and terrestric species, and diversity should be low.

However, 103 species of Plathelminthes have been found in the North Sea salt marshes of the island of Sylt (Armonies, 1987). To resolve this paradox of high species numbers in such an unstable environment, experiments were conducted (Armonies, 1986). The ability to encyst proved to be the main adaptation to survive severe fluctuations of salinity, temperature, oxygen availability, and humidity. Salinity is apparently the main factor causing distribution patterns: most of the abundant salt marsh plathelminths showed clear correlations between abundance and salinity. Thus, individual species occur within distinct ranges of salinity, and some show, similarly, specific 
temperature preferences (Armonies 1986, 1987). Sites or periods with salinity and temperature in the preferred range cause specimens to be active. Unfavourable conditions are endured or avoided in protective cysts.

Because of encystment, rapid changes in plathelminth activity can be observed. Every change in environmental factors will cause some individuals to encyst, while others may leave their cysts and become active. However, environmental conditions are highly patchy in distribution, and they are observed to change at short-term. Thus, corresponding small-scale and short-term variations in community structure are to be expected. As encystment allows the plathelminths to withstand unfavourable conditions, the community should be most complex in the sites with most variable environmental factors.

\section{MATERIAL AND METHODS}

An ungrazed supralittoral salt marsh north of Kampen (island of Sylt, North Sea) was sampled 4 times at 3-month intervals. A complete description of the area is given in Armonies (1987), while here just a few relevant features are mentioned.

For investigation, a $100 \times 10 \mathrm{~m}$ strip of the marsh was chosen. Unlike other supralittoral salt marshes, this area did not desiccate in summer but it always remained humid or even wet. Thus, it is a marine-limnic rather than a marine-terrestric transition zone. The lower part of the marsh (20 to $60 \mathrm{~cm}$ above mean high tide level) is covered by the plant association Puccinellion maritimae (cf. Ellenberg, 1978), with the grass Puccinellia maritima (Huds.) as dominant species. The vegetation height is 20 to $50 \mathrm{~cm}$. The plant association Armerietum maritimae covers the upper part of the marsh. Here, the graminean Festuca rubra (L.) and the juncacean Juncus gerardii Lois. are dominant. The vegetation height is 20 to $30 \mathrm{~cm}$. At about $1 \mathrm{~m}$ above mean high tide level, the brackish water reed Phragmites australis (Cav.) Trin. ex Stend. occurs.

The sediment salinity of the marsh is influenced by fresh water influx, sea water flooding, precipitation, and evaporation. Despite floodings, the uppermost marsh regions always had a salinity lower than sea water, and the salinity was always lower than in the lower marsh regions (Fig. 1). At the island of Sylt, gales are more likely in winter,

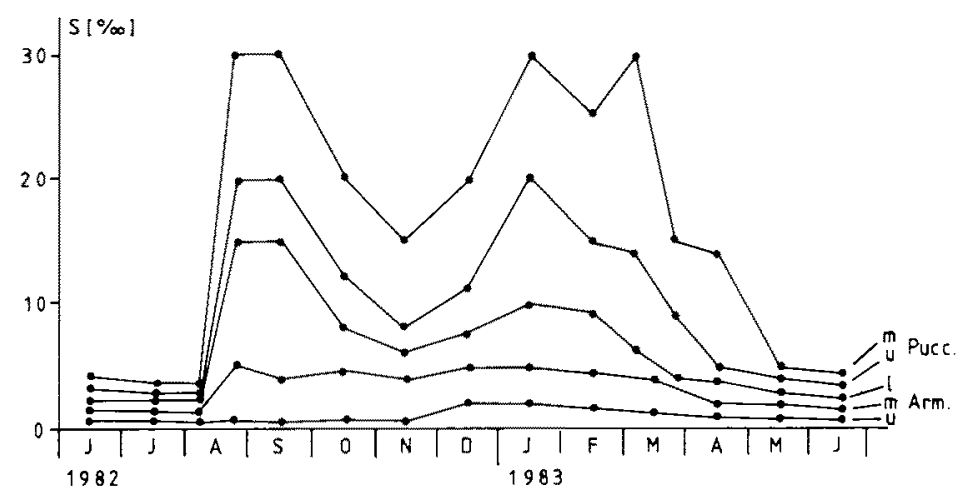

Fig. 1. Salinity (S) in the middle ( $m$ ) and upper (u) part of the plant association Puccinellion maritimae (Pucc,; lower part of the marsh, 1. Pucc., not indicated), and in the $1, \mathrm{~m}, \mathrm{u}$ Armerietum maritimae (Arm., upper part of the marsh). Refractrometrical measurement 
and there is more rain in summer. Thus, the average salinity is higher in winter. According to Figure 2 full seawater-salinity was only observed in the lower and middle Puccinellion, but rainfall can convert the entire marsh into a transient fresh water biotope. Thus, the annual range in salinity is highest in the lower and middle Puccinellion, and lowest in the upper marsh.

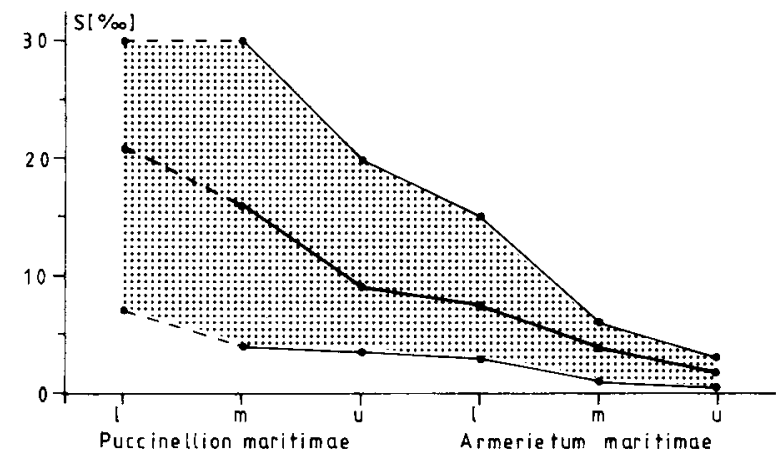

Fig. 2. Annual mean of salinity (solid line) and annual variability of salinity. Broken lines: the values of the lower Puccinellion derived from a smaller number of measurements

The salt marsh surface is spotted with small depressions, and plants form tussocks. Thus, small-scale differences in humidity, sediment composition, detritus content, and related factors such as oxygen availability occur. Differences in vegetative cover alter the rate of evaporation and thus influence salinity. Therefore, environmental conditions are highly patchy. The course of salinity (Fig. 2) gives only averages of this small-scale variance, but the general tendency is present, nevertheless.

The salinity of the thin film of water attached to the aboveground vegetative layer differs from the sediment salinity. Slight rainfall or dew will not significantly alter the sediment salinity, but it was observed to cause considerable changes in the salinity of this thin film of water. Accordingly, evaporation causes considerable changes in the salinity of the vegetative cover, but the sediment salinity is only affected over a long period of time. As a result, dew, rainfall and evaporation alter the salinity inside the vegetation cover aperiodically and more rapidly.

At 3-month intervals, samples were collected at the lower, middle, and upper Puccinellion maritimae (lower part of the marsh), and at the lower, middle, and upper area of Armerietum maritimae (upper part of the marsh). 10 samples of $5 \mathrm{~cm}^{2}$ surface area each were collected at every site at random. In the upper part of Armerietum, however, the number of samples was smaller. Vertically, the samples reached down to the black sediment layer. The anoxic layer below was not sampled. Median grain size (38 to 59 $\mu \mathrm{m}$ ) was similar at all sites. The organic matter content was 22 to $45.5 \%$ of dry weight (combustion method). For extraction, the method described by Armonies \& Hellwig (1986) was used. It yielded quantitative extraction of all metazoan meiofauna taxa except Nematoda. 


\section{RESULTS}

Both the salt marsh sediment as well as the vegetative cover are inhabited by plathelminths. Some species occupy the sediment only, while others are significantly more often in the vegetative layer. Therefore, sediment and vegetative layer may be regarded as structural elements of the habitat salt marsh. Depending on the humidity of the vegetative layer, more species were present in the sediment in June, December, and March. Low evaporation and rainfall in September caused an increase of species numbers in the vegetative layer. With the exception of March, sediment and vegetation together yielded higher numbers of species than one of these structural elements alone (Table 1). In all the months investigated, the faunal similarity between sediment and

Table 1. Plathelminth species numbers in salt marsh sediment (s), vegetation cover ( $v$ ), and both combined (comb). U-test refers to numbers of species in each of the 20 samples of the lower and middle zone of the plant association Puccinellion maritimae

\begin{tabular}{|lccccccc}
\hline & \multicolumn{4}{c}{ Number of species in } & & \multicolumn{2}{c}{ - U-test - } \\
Month & $\mathrm{s}$ & $\mathrm{v}$ & $\mathrm{comb}$ & $\mathrm{s}-\mathrm{v}$ & $\mathrm{s}$-comb & $\mathrm{v}$-comb \\
\hline June & 35 & 32 & 39 & $\mathrm{~ns}$ & $\mathrm{p} \leq 0.001$ & $\mathrm{p} \leq 0.01$ \\
Sept & 26 & 33 & 36 & $\mathrm{~ns}$ & $\mathrm{p} \leq 0.01$ & $\mathrm{p} \leq 0.05$ \\
Dec & 42 & 31 & 44 & $\mathrm{p} \leq 0.01$ & $\mathrm{p} \leq 0.05$ & $\mathrm{p} \leq 0.001$ \\
March & 43 & 33 & 43 & $\mathrm{p} \leq 0.001$ & $\mathrm{p} \leq 0.05$ & $\mathrm{p} \leq 0.01$ \\
\end{tabular}

vegetative layer within samples is higher than faunal similarity between parallel samples (Table 2).

When sediment and vegetative cover are considered together, the highest numbers of species and the highest species densities are always found in the middle Puccinellion (Table 3). On average, this region is also richest in individuals (Table 4), and the diversity $\mathrm{H}^{\prime}$ (Shannon-Weaver) is highest (Table 5).

From Figure 2, an average salinity can be derived for every zone of the marsh. The number of plathelminth species found in each zone was highest when the salinity measured at sample collection was near this annual mean (Fig. 3). The total number of species found after 4-fold sampling is highest in the middle Puccinellion (Fig. 4), which has an annual mean salinity of $15 \%$. If these species numbers are compared to the annual variation of salinity, a linear relationship is observed (Fig. 5).

The relation between individual abundance and salinity is more complex. In the lower marsh, the abundance of individuals is highest when salinity is near the annual

Table 2. Renkonen similarity of sediment and vegetation layer (structures) and of parallel samples (parallels) of the lower and middle Puccinellion maritimae (in percent)

\begin{tabular}{|lccccc|}
\hline & June & September & December & March & Mean \\
\hline Structures & 61.3 & 73.1 & 45.6 & 49.0 & 55.4 \\
Parallels & 44.4 & 31.6 & 36.5 & 38.3 & 37.7 \\
\hline
\end{tabular}


mean. In the upper marsh, however, the contrary is true (Fig. 6). The number of individuals found is lowest when salinity approaches the annual mean. Here the response of individual species dominates the combined abundance of the respective assemblages.

Table 3. Plathelminth species numbers $\left(50 \mathrm{~cm}^{2}\right.$ of sample surface) and mean species density per 10 and $100 \mathrm{~cm}^{2}$. The values of the upper Armerietum refer to a smaller number of samples

\begin{tabular}{|c|c|c|c|c|c|c|c|}
\hline Region & Jun & Sep & Dec & Mar & Total & $\mathrm{sp} / 10 \mathrm{~cm}^{2}$ & $\mathrm{sp} / 100 \mathrm{~cm}^{2}$ \\
\hline 1 Pucc & 27 & 38 & 27 & 17 & 50 & 15.5 & 43.5 \\
\hline $\mathrm{m}$ Pucc & 30 & 32 & 34 & 35 & 53 & 20.3 & 47.0 \\
\hline u Pucc & 30 & 27 & 28 & 28 & 45 & 16.3 & 41.0 \\
\hline l Arm & 15 & 10 & 11 & 11 & 24 & 6.2 & 20.5 \\
\hline m Arm & 6 & 7 & 4 & 3 & 14 & 1.6 & 9.5 \\
\hline $\mathrm{u}$ Arm & 3 & 2 & 3 & 4 & 5 & 1.0 & 4.3 \\
\hline Total & 49 & 53 & 49 & 48 & 66 & 11.3 & 45.2 \\
\hline
\end{tabular}

Table 4. Plathelminth abundance per $10 \mathrm{~cm}^{2}$ of sample surface. In the upper Armerietum, a smaller number of samples was collected and this site was excluded here

\begin{tabular}{|lccccc|}
\hline Region & June & September & December & March & Mean \\
\hline I Pucc & 200.2 & 125.0 & 71.4 & 69.4 & 116.5 \\
m Pucc & 213.4 & 87.4 & 295.2 & 344.0 & 235.0 \\
u Pucc & 186.0 & 119.0 & 80.0 & 152.6 & 134.4 \\
I Arm & 45.8 & 25.8 & 17.4 & 30.6 & 29.9 \\
m Arm & 24.0 & 6.6 & 1.8 & 1.0 & 8.3 \\
Mean & 133 & 73 & 92 & 119 & 104 \\
\hline
\end{tabular}

Table 5. Diversity $H^{\prime}$ (Shannon-Weaver, $\mathrm{n}$ ) of the salt marsh plathelminth fauna. All values refer to $10 \mathrm{~cm}^{2}$ of sample surface, but the values of the upper Armerietum were calculated from a smaller number of samples

\begin{tabular}{|lccccc|}
\hline Region & June & September & December & March & Mean \\
\hline I Pucc & 2.06 & 2.37 & 1.96 & 1.91 & 2.08 \\
m Pucc & 2.09 & 2.33 & 1.90 & 2.14 & 2.11 \\
u Pucc & 2.08 & 1.92 & 2.12 & 2.09 & 2.05 \\
I Arm & 1.61 & 1.33 & 1.44 & 1.24 & 1.40 \\
m Arm & 0.53 & 0.66 & 0.87 & 0.64 & 0.67 \\
u Arm & & 0.52 & 0.67 & 0.74 & 0.63 \\
Mean of Pucc & 2.08 & 2.21 & 1.99 & 2.05 & 2.08 \\
Mean of Arm & 1.07 & 0.84 & 0.99 & 0.87 & 0.94 \\
Total mean & 1.67 & 1.52 & 1.51 & 1.46 & 1.54 \\
\hline
\end{tabular}


This change is closely related to the annual course of salinity. In the lower marsh regions, changes in salinity are episodic. In the upper marshes, however, there is an annual fluctuation of salinity. In summer, salinity is lower than the annual mean, and is higher in winter. Thus, the annual mean of salinity is actually present only during some days of the year. When salinity falls below the annual mean, only those plathelminth species preferring low salinity are active. Increasing salinity will diminish their abun-

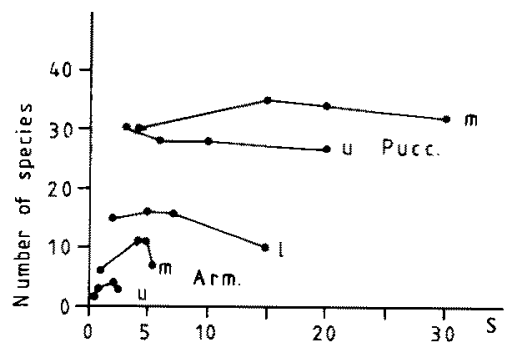

Fig. 3. Number of plathelminth species and salinity (S) at sample sites. The salinity of the lower Puccinellion could not be measured everytime. Therefore, this site was excluded here (see also Fig. 1)

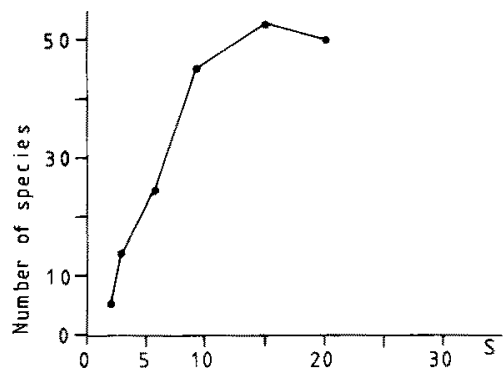

Fig. 4. Number of plathelminth species per sample site related to the annual mean of salinity

Enol variation of salinity

number of plathelminth species

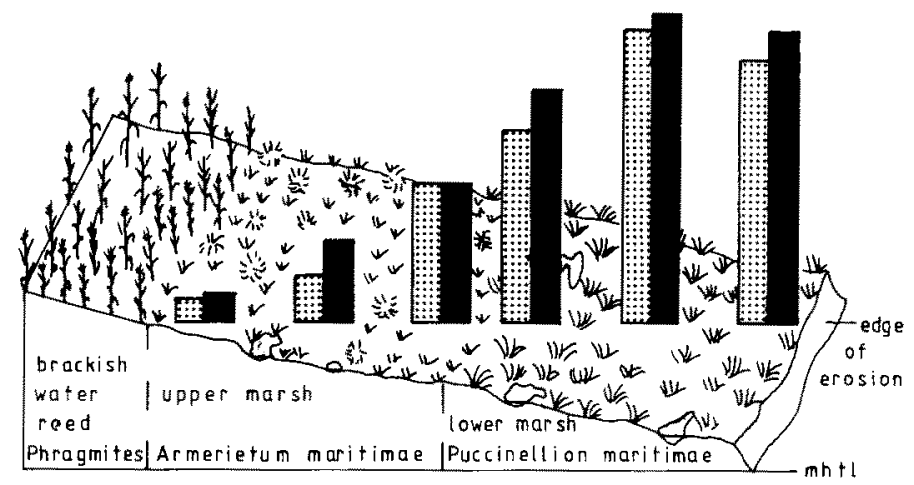

Fig. 5. Number of plathelminth species per sample site related to the annual variability of salinity 


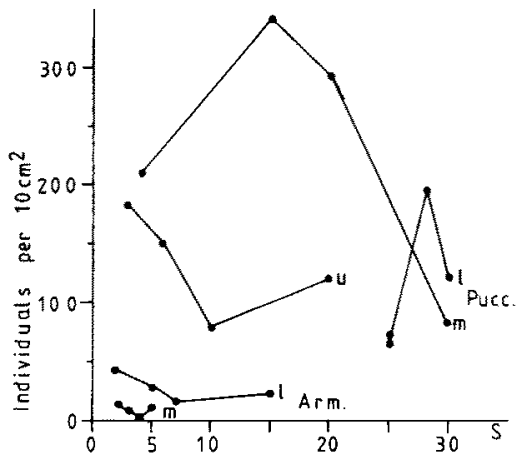

Fig. 6. Average plathelminth abundance (individuals below $10 \mathrm{~cm}^{2}$ of surface area) related to the annual mean of salinity at sample sites

dance. When salinity approaches the annual mean, most of these low-salinity species are present with few individuals only. At the same time, some individuals of species preferring higher salinity will be already present. When salinity continues to increase, the lower salinity species will disappear, and the species preferring higher salinity will become more abundant. Thus, when salinity has reached the annual mean, the number of species is highest and the number of active individuals is lowest (Figs 3,6). The plathelminth fauna of upper salt marsh regions is divided into lower and higher salinity species.

The faunal similarity of the plathelminths from the 10 parallel samples of each site demonstrates the small-scale heterogenity of the salt marsh environment (Table 6). On

Table 6. Renkonen similarity (in \%) of the plathelminth fauna in parallel samples. Average similarity of all combinations of the 10 parallels (only 4-6 parallels in upper Armerietum)

\begin{tabular}{|llcccrr|}
\hline \multicolumn{2}{|c}{ Region } & June & September & December & March & Mean \\
\hline l Pucc & 45.2 & 32.2 & 36.1 & 36.3 & 37.5 \\
m Pucc & 38.0 & 32.2 & 39.7 & 45.7 & 39.0 \\
u Pucc & 50.8 & 30.9 & 33.2 & 30.9 & 36.5 \\
I Arm & 29.3 & 39.5 & 18.2 & 40.4 & 32.0 \\
m Arm & 31.7 & 0.3 & 0.4 & 4.4 & 9.2 \\
u Arm & - & - & 3.7 & 7.2 & 5.5 \\
Mean & 39.0 & 27.2 & 21.7 & 25.8 & 28.4 \\
\hline
\end{tabular}

an average, similarity is less than $40 \%$ (Renkonen similarity). The lower marsh sites display the largest fluctuations in salinity, and the faunal similarity of parallel samples is highest. If the range of salinity is high in each sample, differences to others cannot be so large. In areas with minor fluctuations in salinity (upper marsh), the average similarity of parallel samples is smallest. Here, a slight difference in salinity may cause completely different species to leave their cysts and become active (Armonies, 1986). Thus, the 
plathelminth faunal composition is most stable in sites where salinity is most unstable (Fig. 7). The plathelminths of salt marshes are adapted to environmental instability (Armonies, 1986, 1987).

\section{DISCUSSION}

\section{Environmental instability affects species numbers}

Salt marsh plathelminths are able to encyst as soon as the environment deteriorates. Lack of oxygen and decreasing water content of sediment affect all plathelminth species in a similar way. These factors alter the total plathelminth activity more than the species
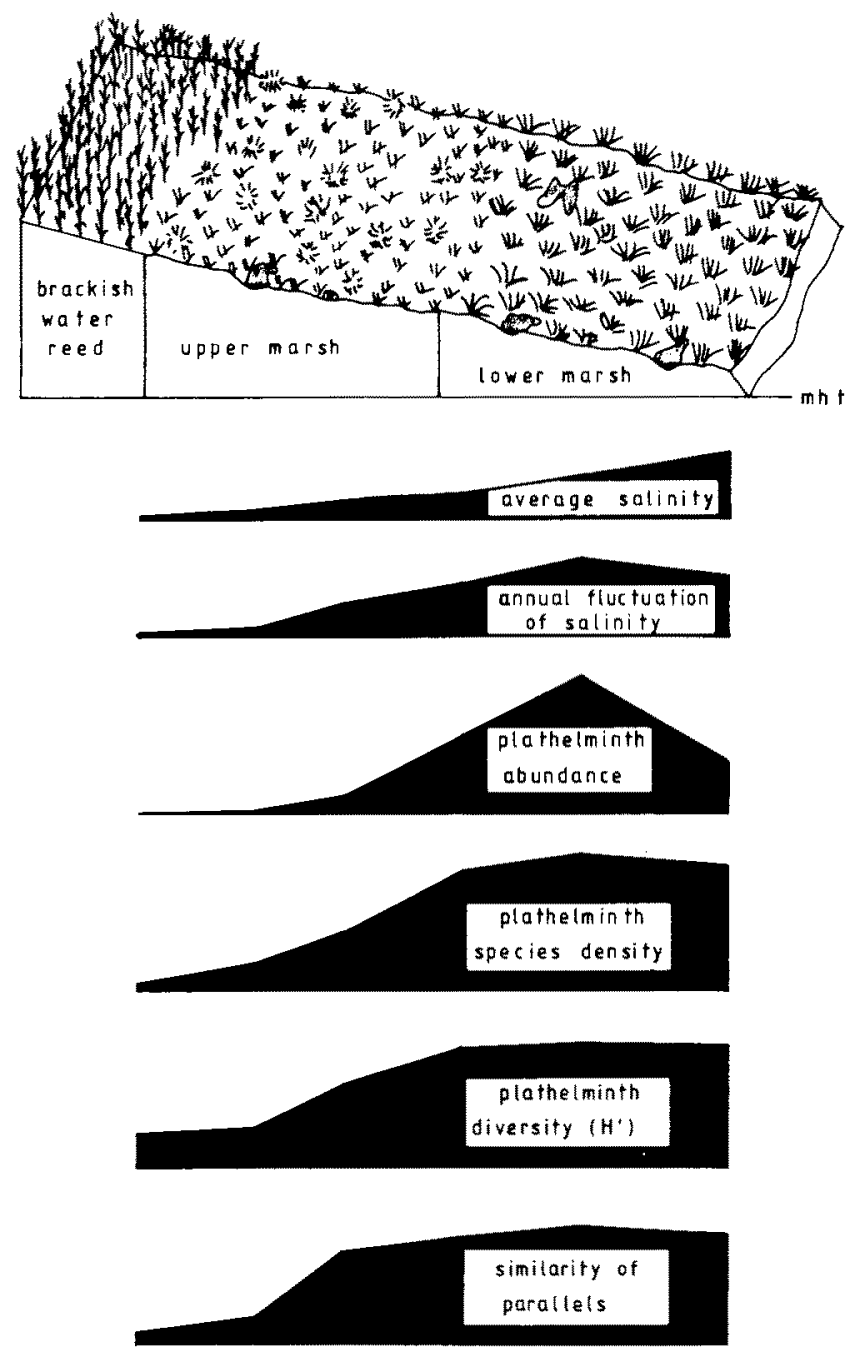

Fig. 7. Annual mean and annual variability of salinity, and plathelminth abundance, species density, diversity, and the similarity of parallels. Relative scales, from the data given in Tables 3-6 
composition (Armonies, 1986). In the salt marsh sampled there were no regular spatial gradients of oxygen or humidity. There is no difference in temperature between the sites that would explain the faunal gradient.

Salinity, therefore, seems to be the most important factor (Armonies, 1986). With regard to the assemblage of plathelminths in the supralittoral salt marshes of the North Sea, environmental instability is equivalent to changes in salinity. Individual species are active only when salinity is in the preferred range, otherwise they are encysted. Therefore, a wide range of salinity (equivalent to high environmental instability) allows many species to fit in at one time or another. Conversely, lower numbers of species are expected in taxa that tolerate wide ranges of environmental factors and remain active.

The Oligochaeta seem to tolerate wide ranges of salinity as well as other factors (Giere, 1980; Giere \& Pfannkuche, 1982). Consequently, relatively few species have been found in the salt marshes of the North Sea (Kossmagk-Stephan, 1985). About 90 species of Nematoda have been recorded from the salt marshes and mud flats of the North Sea (Lorenzen, 1969). Because of the similar number of nematode and plathelminth species, a small-scale nematode distribution pattern similar to plathelminths is to be expected.

\section{Diversity in salt marshes compared to the entire littoral zone}

While the salt marsh regions with the more unstable environmental conditions (i.e. salinity) display a high diversity of plathelminths, the total diversity of the salt marsh plathelminth fauna is rather low (Table 7). Only occasionally does the plathelminth diversity in the lower regions of the supralittoral salt marsh reach the $H$-values of an adjacent intertidal mud flat (see Dittmann \& Reise, 1985). Further seaward in the tidal zone, diversity of plathelminths is always higher than in the supralittoral salt marshes.

Table 7. Number of plathelminth species and plathelminth diversity $(H$, Shannon-Weaver) in tidal sediments of the island of Sylt

\begin{tabular}{|lcrl|}
\hline Tidal zone & $H^{\prime}$ & Species & Author \\
\hline Supralittoral salt marshes & 1.54 & 103 & Armonies (1987 and Table 5) \\
Intertidal mud flat & 2.10 & 49 & Dittmann \& Reise (1985) \\
Intertidal sand flat & 3.35 & 83 & Reise (1984) \\
Semi-exposed sand flat & & 59 & Xylander \& Reise (1984) \\
$\quad$ near low tide level & 2.6 & 121 & Wehrenberg \& Reise (1985) \\
Sublittoral sand, 2 years & 3.30 & & \\
& 3.01 & & \\
\hline
\end{tabular}

The decreasing landward trend in diversity $\left(H^{\prime}\right)$ may be caused by increasing environmental harshness. For marine species, the euhaline subtidal zone is certainly more favourable than the supralittoral zone. However, most of the plathelminths living in the supralittoral salt marshes of the North Sea are brackish-water species that are 
absent from the intertidal and subtidal zones of the North Sea. Therefore, the number of plathelminth species does not remarkably decrease along the tidal gradient of the North Sea (Table 7).

\section{Salt marsh sites compared for plathelminth diversity}

There are two striking features in the plathelminth diversity pattern of the North Sea littoral zone. Firstly, with increasing environmental harshness the average diversity $H^{\prime}$ decreases in landward direction, while the total number of species remains rather high. Secondly, within the supralittoral salt marshes increasing environmental instability results in increasing diversity ( $H^{\prime}$ as well as the number of species present). Thus, environmental instability reduces the diversity in the littoral gradient, but it increases diversity within the supralittoral salt marshes.

This opposing influence of environmental instability is accompanied by a change in the plathelminth species composition. The subtidal zone of the North Sea is inhabited by marine species, and the plathelminths living in the intertidal are marine species presumably able to tolerate intermittent salinity reductions. The supralittoral salt marshes, however, are occupied by truly brackish-water species, most of which are not found in the intertidal zone (Armonies, 1986). This change from marine to brackish water species essentially takes place near mean high tide level (Hellwig, 1987).

For marine species the increasing fluctuations of salinity mean harsh and unpredictable conditions, and few species are able to tolerate this instability. Therefore, the number of marine species constantly diminishes along the tidal gradient. In the supralittoral salt marshes, on the other hand, environmental instability is a permanent feature. Thus, adaptation to environmental instability has evolved. For appropriately adapted species, environmental instability is no longer restricting. It allows them to occupy a habitat where they are free from competition by animals from adjacent zones.

The dominant plathelminth species of these supralittoral salt marshes of the North Sea have been shown to prefer distinct ranges in salinity (Armonies, 1986, 1987). Together with encystment this is one of the adaptations which help them cope with salinity fluctuations. With these adaptations, a wide range of salinity (equivalent to high rates of salinity fluctuations) offers niches to many species. In areas of lower salinity fluctuations, as occurs in the uppermost region of the salt marsh, the number of potential niches is reduced. Thus, the observed pattern of plathelminth diversity within the supralittoral salt marshes of the North Sea seems to be a consequence of salinity preferences.

Looking for a general theory of diversity to explain the plathelminth diversity pattern in the supralittoral salt marshes and the littoral zone of the North Sea, the more simple models collapse due to the contradictory influence of environmental instability on marine and brackish water plathelminths (see Thiery, 1982). Because of the high environmental instability, the salt marsh plathelminth fauna is unlikely to exist in a state of equilibrium. Therefore, the idea that high diversity can only be maintained in a state of nonequilibrium is to be included in a general theory of diversity (e.g. Connell, 1978).

Huston (1979) combined nonequilibrium, environmental instability, and competition in his "dynamic equilibrium model", which seems to be able to explain the salt marsh plathelminth community structure as well as the decrease in diversity along the 
littoral gradient. This model is based on differences in the rates at which populations of competing species approach competitive equilibrium.

The hypothesis assumes that most communities exist in a state of nonequilibrium where competitive equilibrium is prevented by periodic population reductions and environmental fluctuations. When competitive equilibrium is prevented, a dynamic balance may be established between the rate of competitive displacement and the frequency of population reduction, which results in a stable level of diversity (Huston, 1979).

The influence of environmental fluctuations on the salt marsh plathelminth community has already been demonstrated. Thus, the rate of competitive displacement should be highest in those regions of the marsh which have the most stable environment, causing the diversity to be low. High environmental fluctuations should reduce the rate of competitive displacement, and diversity should be high. Indeed, this is the observed pattern of diversity, and the level of diversity was stable in every zone of the marsh (see Table 5). Moreover, according to Huston's model, a high rate of environmental fluctuation should cause the rate of competitive displacement to be low, and in the salt marsh plathelminth fauna there was no hint of significant competition actually taking place (Armonies, unpubl. data). However, there was also no hint of competition among the few species living in the most stable uppermost zone of the supralittoral salt marshes. In addition, abundance of these species is low. Thus, although the model is able to give applicable predictions on the course of diversity, there is little evidence for the involved causality also being applicable.

Acknowledgements. I thank Prof. Dr. P. Ax and Dr. K. Reise for their continuous interest and support in this study. The Biologische Anstalt Helgoland, Litoralstation List, generously provided superb laboratory facilities.

\section{LITERATURE CITED}

Armonies, W., 1986. Free-living Plathelminthes in North Sea salt marshes: adaptations to environmental instability. - J. exp. mar. Biol. Ecol. (In press).

Armonies, W., 1987. Freilebende Plathelminthen in supralitoralen Salzwiesen der Nordsee: Okologie einer borealen Brackwasser-Lebensgemeinschaft. - Microfauna mar. 3 (in press).

Armonies, W. \& Hellwig, M, 1986. Quantitative extraction of living meiofauna from marine and brackish muddy sediments. - Mar. Ecol. Progr. Ser. 29, 37-43.

Connell, J. H., 1978. Diversity in tropical rain forests and coral reefs. High diversity of trees and corals is maintained only in a nonequilibrium state. - Science, N. Y. 199, 1302-1310.

Dittmann, S. \& Reise, K., 1985. Assemblage of free-living Plathelminthes on an intertidal mud flat in the North Sea. - Microfauna mar. 2, 95-115.

Ellenberg, H, 1978. Vegetation Mitteleuropas mit den Alpen in ökologischer Sicht. Ulmer, Stuttgart, $989 \mathrm{pp}$.

Giere, O. W., 1980. Tolerance and preference reactions of marine Oligochaeta in relation to their distribution. In: Aquatic oligochaete biology. Ed. by R. O. Brinkhurst \& D. O. Cook. Plenum Press, New York, 385-409.

Giere, O. \& Pfannkuche, O., 1982. Biology and ecology of marine Oligochaeta, a review. Oceanogr. mar. Biol. 20, 173-308.

Hellwig, M., 1987. Okologie freilebender Plathelminthen im Grenzraum Watt - Salzwiese lenitischer Gezeitenküsten. - Microfauna mar. 3 (in press).

Huston, M., 1979. A general hypothesis of species diversity. - Am. Nat. 113, 81-101.

Koßmagk-Stephan, K.-J., 1985. Systematik, Faunistik und Lebenszyklus mariner Oligochaeta der Nord- und Ostseeküste. Diss., Univ. Göttingen, 306 pp. 
Lorenzen, S, $_{1969}$. Freilebende Meeresnematoden aus dem Schlickwatt und den Salzwiesen der Nordseeküste. - Veröff. Inst. Meeresforsch. Bremerh. 11, 195-238.

Reise, K., 1984. Free-living Plathelminthes (Turbellaria) of a marine sand flat: an ecological study. Microfauna mar. 1, 1-62.

Thiery, R. G., 1982. Environmental instability and community diversity. - Biol. Rev. 57, 691-710.

Wehrenberg, C. \& Reise, K., 1985. Artenspektrum und Abundanz freilebender Plathelminthes in sublitoralen Sänden der Nordsee bei Sylt. - Microfauna mar. 2, 163-180.

Xylander, W. \& Reise, K., 1984. Free-living Plathelminthes (Turbellaria) of a rippled sand bar and a sheltered beach: a quantitative comparison at the island of Sylt (North Sea) - Microfauna mar. 1, 257-277. 